\title{
THE INFLUENCE OF SOCIO-ECONOMIC VARIABLES ON ADOPTION BEHAVIOUR TOWARDS TADCO IMPROVED RICE PARBOILING TECHNIQUE AMONG RICE PARBOILERS IN KURA PROCESSING AREAS OF KANO STATE, NIGERIA.
}

\author{
${ }^{1}$ Alimi, H. M And 2Zango M. I. \\ ${ }^{*}$ General Studies Department, Federal College of Agricultural Produce Technology Kano, Nigeria \\ ${ }^{*}$ Department of Sociology, Bayero University Kano, Nigeria \\ Corresponding Email: halibidecs@yahoo.com \\ 08034848208
}

\begin{abstract}
Among the reason put forward for the huge consumption and preference for foreign rice is the use of improved techniques employed by developed countries in producing high grade and pebble free rice. This study therefore examines the influence of socio-economic variables on the adoption behavior of rice parboilers towards Tadco improved rice parboiling technique among female parboilers in Kura rice processing Areas of Kano State. Cluster sampling was used with a sample size of six hundred and ninety eight respondents (698). Data collection and analysis were carried out using mixed method. Data was collected using a structured questionnaire and Focus group discussion while the analysis was done using frequency distribution, Logistic regression and content analysis. The analysis revealed that majority of the respondents is of low educational level, income and exposure to modern rice parboiling technique. Awareness of tadco parboiling technique was very high but the adoption is rather low. Age and educational level were found to be associated with non adoption with socio-economic variables explaining between $2.6 \%$ and $16.2 \%$ of variation in non adoption of tadco parboiling technique. Educational level is positively related $(p<0.05)$ while age is negatively related with the dependent variable. Evidence from the Focus group discussion showed that the huge non adoption recorded is as a result of non favourability of the technique. The advantage is seen in skills acquisition and confidence booster which has helped them greatly using their traditional method. The study concluded that education of the rural women should be prioritized, gap in gender disparity bridged by technology manufacturer while designing improved techniques. A viable feedback mechanism should exist between innovation manufacturer and the end users to provide solution to any shortcoming that might come up in the course of technology use.
\end{abstract}

Keywords: socio-economic variables, female rice parboilers adoption behaviour,

\section{INTRODUCTION}

The percentage of food insecure households in Nigeria was reported to be $18 \%$ in 1986 and over $41 \%$ in 2004 (Aminu et. al., 2010) with the poor people, especially those in rural areas, being hard hit by the phenomenon as most of the rural households lack access to sufficient resources to produce or buy quality food. Agriculture is the most important sector of the economy in terms of rural employment, sufficiency in food and fiber, and export earning prior to the discovery of oil. It provides direct employment to about $75 \%$ of the population in the country and is the largest economic sector in Kano State, with $70 \%$ of the working population directly or indirectly engaged in agricultural activities ((NBS, 2007) (Badayi and Said 2006, 2011).

Rice (Oryza sativa L.) is one of the world's most important food crops and consume as a staple food for more than fifty percent of world's population particularly in India, China and developing countries in Africa (Daramola 2005; Okoruwa and Ogundele 2006). Total consumption of rice in Nigeria stands at about 4.4 million metric tons of milled rice, while annual consumption per capital stands at $29 \mathrm{~kg}$ and this has 
continued to rise at $11 \%$ per annum (USAID MARKET, 2010). This has led the gap between domestic supply and demand to continue to increase (FMARD, 2012). As a result of this, the quantity of rice import into Nigeria has risen from 300,000 metric tons in 1995 to 794,000 metric tons in 2000 (Akpokodje et. al., 2003) while the country in the largest rice importer in West Africa and the second largest importer in the world with an annual average import of 1.6million metric tons as at 2010. (USAID MARKET, 2010). The country buy at least 2 million tonnes per year from exporting countries like China and Thailand (Onwalu, 2012) thereby spending about N360 billion annually on rice importation Adekunle, 2013).

Rural dwellers, particularly women play a vital role in food production and food security. They account for seventy percent of agricultural workers, eighty percent of food producers and are engaged in the processing of basic foodstuffs. In Nigeria, women produce $60-80 \%$ of the agricultural food in the country. Not only are women the mainstay of the agricultural food sector, labour force, and food systems, they are also largely responsible for post-harvest activities such as storage and processing (Mafimisebi, 2007; Mohammed and Adullahi, 2012). Women are constrained from embarking on non- farm enterprises by limited access to and control of productive resources such as startup capital, inadequate credit access and land procurement barriers (Osondu, 2014).

Personal characteristics can be referred to as the socio-economic and demographic factors of individuals. Sanun (1997) cited in Jamsari et. al., (2012). Age has been found to be significant to adoption of improved processing technique among women processors. Eziehe et. al., (2014) discovered in their study that majority of $69.7 \%$ of the women soybeans processors in Tarka LGA of Benue State Nigeria fell within the ages of 21-40 years. This is due to the fact that soybean processing is labour intensive and mostly done by middle age women, this implies that age group influences processing operation. Also in Tafawa Balewa Local Government Area of Bauchi State, Nigeria, Fabiyi and Hamidu (2011) found out that there was a significantly positive $(\mathrm{P}<0.05)$ correlation between age and the adoption of the improved soyabean technologies in the study area.

Educating girls is one of the most powerful tools for women's empowerment. Education provides women with the knowledge, skills and self-confidence they need to seek out economic opportunities. Education is therefore viewed as an unfailing engine of change and the chief instrument through which society socializes its members for bringing desirable changes. Research has found the premises above to be true as, Agbamu et. al., (1996) and Ezebuiro (2008) posited that level of education among farmers yielded positive significant relationship to adoption of improved varieties and technologies. The more the farmers advance in their level of education, the more they tend to understand the importance, intricacies and need for adopting new improved farm practices.

The sources of information which farmers in developing countries use is dependent on their education level, age group, kind of information sources available in a given community, kind of innovation and extent of modernization in a locality. Also, local network provides information and serve as a source of obtaining credit. However, belonging to local network or association will improve the probability of access to credit for members which can be channelled towards improving their livelihood activities (Anyiro et al 2015). Studies have shown that there is an obvious positive relationship between level of income and adoption of agricultural innovations. The higher the income level of a farmer, the lesser he/she will be disposed to the fear of taking a risk as regards a given technology. The study of Agbamu et. al., (1996) confirmed that the economic status of the farmers showed positive and significant relationship with adoption and was specific about farm income making a significant contribution to adoption. The poor economic status of most Nigerian farmers has inhibited the adoption of most agricultural technologies especially the female farmers as most women are of low income status thereby limiting their opportunity for broader participation in society compounded by the trouble they experienced in child bearing and rearing (Ejembi et. al., 2006) 
The quality of the local rice is a major concern for the future of the Nigerian rice sector; while part of the issue relates to the biophysical properties of the varieties locally produced, the major problem is the appearance and the cleanliness of the rice delivered to the market. Sequel to the aforementioned points, an improved parboiling technique was introduced to the rice parboilers by PrOpCom (Promoting ProPoor Opportunities through Commodity and Service Markets) in order to improve the appearance, cleanliness and the general quality of processed rice by the women parboilers. The design incorporates a false bottom to facilitate steaming versus cooking and taps to aid the evacuation of hot water once soaking is complete. (PrOpcom newsreel, 2007). The study generally aims at examining the influence of socio-economic variables on the adoption of tadco improve rice parboiling technique among the female parboilers in Kura processing areas of Kano State. The specific objectives are to

i describe the socio economic characteristics of the female parboilers in the study area;

ii determine the adoption level of the techniques among the female parboilers in the study area; and

iii determine the influence of socio-economic variables on adoption behavior of the respondents in the study area.

The hypothesis which state that a relationship exists between socio-economic variables of parboilers and their adoption behaviour towards tadco parboiling technique will be tested.

\section{METHODOLOGY}

The study area is Kano-Kura rice processing Area of Kano state of Nigeria. It is geographically located in the southern part of the state along a dual express way of Zaria- Kano road which has a distance of about $35 \mathrm{~km}$ from the state capital. It is located at 110 46' $17^{\prime \prime} \mathrm{N}$ to $80^{\circ} 25^{\prime} 49 \mathrm{E}$ and covers an area of about $206 \mathrm{~km}^{2}$ of cultivated land with a population of about 14,601 (2006 census). It is known for the production of food stuffs and vegetable crops both during dry season and raining season. The dry season mostly start from October to April while the raining season begins from April to September with an average annual rainfall of $134.4 \mathrm{~m}$. The people are $80 \%$ farmers who are engaged in mixed farming with an extensive use of irrigation farming. Some of the crops produced are rice, wheat, maize, millt, beans, tomatoes, sugarcane .cabbage etc. It therefore has a significant number of producers, processors and quality oriented retail markets for both paddy rice and milled local rice across the state.

The Population of the study is the female rice processors in Kura rice processing area of Kano State. The list of participants (sampling frame ) was extracted from Propcom Monograph Series No 24, Titled "Managing Demonstration of Improve parboiling Equipment in Kura-Kano Rice Processing Cluster". The frame consists of Seven sites with each site treated as a cluster, Samples were selected from each using a random sampling technique. .A total of seven hundred and fifty (750) questionnaires were given out and a total of six hundred and ninety eight (698) were found useful for the analysis as the others claimed they have no knowledge of the technique. A focus group interview was also conducted. The data was analyzed using frequency distribution, logistic regression and content analysis. 
Table 1: Distribution of Number of Parboilers by Clusters

\begin{tabular}{llc}
\hline Serial no & Clusters & Number of female parboilers \\
\hline 1. & Kura Fegindauda & 110 \\
2. & Kura Bakintiti & 106 \\
3. & Garko & 65 \\
4 & Tundunwada & 87 \\
5. & Chiromawa & 213 \\
6 & Tanburawa & 48 \\
7. & Karfi & 70 \\
& TOTAL & 698
\end{tabular}

Field Survey 2014

The data obtained were analysed with the logistic regression model, expressed as Let: $\operatorname{Pi}=\operatorname{Pr}(\mathrm{Y}=1) / \mathrm{X}=\mathrm{xi})$

$\log P i /(1-P i)=\operatorname{logit}(P i)=\beta 0+\beta 1 x i$

If $\mathrm{Pi}$ is the probability of adopting tadco parboiling technique, and $\mathrm{xi}$ is a vector of independent variables. Therefore, the parameter $\beta 0$ gives the log odds of a young female parboiler adopting tadco technique (when $\mathrm{xi}=0$ ) and $\beta 1$ shows how these odds differ for older category parboiler (when $x i=1$ ). We can write the model in terms of odds as: $\mathrm{Pi} /(1-\mathrm{Pi})=\exp (\beta 0+\beta 1 \mathrm{xi})$ Or in terms of the probability of the outcome $\mathrm{Pi}=$ $\exp (\beta 0+\beta 1 x i) /(1+\exp (\beta 0+\beta 1 x i))$

The statistical model for logistic regression is $\log (p / 1-p)=\beta 0+\beta 1 \times$ where $p$ is a binomial proportion and $x$ is the explanatory variable. The parameters of the logistic model are $\beta 0$ and $\beta 1$

Logistic regression equation for personal characteristics is given as follows:

Logit $P=\beta 0+\beta_{1} X_{1}+\beta_{2} X_{2}+\beta_{3} X_{3}+\beta_{4} X_{4}+\beta_{5} X_{5}+\beta_{6} X_{6}+\beta_{7} X_{7}+\beta_{8} X_{8}$

Where

$X_{1}=$ Age of Parboilers (years)

$X_{3}=$ Parboilers' Parboiling experience (years)

$X_{5}=$ Parboilers' Occupational Membership

$\mathrm{X}_{2}=$ Educational level of parboilers

$X_{4}=$ Parboiler's income level (per annum)

$X_{7}=$ Parboilers' Exposure level to Improve technique $\quad X_{8}=$ Parboilers' marital status.

Age of parboilers is categorized into two namely; younger and older category. The younger category are parboilers who are 40years and below while the other category are those respondents who are older than 40years of age.

\section{RESULT AND DISCUSSION}

From table 2, almost all respondents are married (96.3\%). More than half of the female parboilers $(54.2 \%)$ are within the age range of $31-35 y$ rs, followed by $21.2 \%$ of parboilers who are between $36-40$ years of age; this indicates that majority of the female parboilers are in their productive and reproductive age. Almost all participants are member of parboilers association (97.4\%) while only $2.6 \%$ of them are no members. Most of the rice parboilers $97.6 \%$ have a working experience of 6years and above, while only $2.4 \%$ have an experience of less than 6years which implies that the female parboilers are well experienced in their occupation.

The exposure level of parboiler to improve parboiling techniques is expected to influence their attitude towards adoption. From the result, a large percentage of the female parboilers; $86.7 \%$ are not exposed 
to other processing technique other than their traditional shafa technique while only $12.3 \%$ are familiar with other technique. More than half of the respondents $(59.3 \%)$ can be categorized as low income earners (Parboilers who earn not more than N150, 999:00k), $8.5 \%$ are average income earners (N160,000-209,999) while $32.3 \%$ can be said to be high income earner (N210,000 and above). The income level recorded is in line with the findings of Osondu (2014) which stated that low income is one of the barriers for rural women embarking on nonfarm enterprise. A huge percentage of the female respondents attended Qur'anic/lslamiyah school (95.3\%), and are categorized as parboilers with low educational level, followed by holders of primary school certificate (3.2\%) and are referred to as parboilers with medium educational level while parboilers who pass through secondary education and more; $1.5 \%$ are categorized as parboilers having high educational level. The finding is in agreement with Matanmi and others (2011) who posited in their study that $77 \%$ of the respondents interviewed had no formal education with only $3.3 \%$ having secondary education

TABLE 2: Demographic and Socio Economic Characteristics of Respondents ( $\mathrm{N}=698$ )

\begin{tabular}{|c|c|c|}
\hline Variables & Frequency & Percentage \\
\hline \multicolumn{3}{|l|}{$\overline{\text { Age }}$} \\
\hline Below 25yrs & 1 & 0.1 \\
\hline $25-30 y r s$ & 121 & 17.3 \\
\hline $31-35 y r s$ & 378 & 54.2 \\
\hline $36-40 y r s$ & 148 & 21.2 \\
\hline 41-46yrs & 33 & 4.7 \\
\hline $46-50 y r s$ & 17 & 2.4 \\
\hline \multicolumn{3}{|l|}{ Marital Status } \\
\hline Single & 12 & 1.7 \\
\hline Married & 672 & 96.3 \\
\hline Widow & 3 & 0.4 \\
\hline Divorce & 11 & 1.6 \\
\hline \multicolumn{3}{|c|}{$\begin{array}{l}\text { Membership of Professional } \\
\text { Organization }\end{array}$} \\
\hline Member & 680 & 97.4 \\
\hline Non Member & 18 & 2.6 \\
\hline \multicolumn{3}{|l|}{ Parboiling Experience } \\
\hline$<6 y r s$ & 17 & 2.4 \\
\hline$>6 y r s$ & 681 & 97.6 \\
\hline \multicolumn{3}{|c|}{ Level of exposure to Improve } \\
\hline Expose & 93 & 13.3 \\
\hline Not Expose & 605 & 86.7 \\
\hline \multicolumn{3}{|l|}{ Income level (Per annum) } \\
\hline Low level & 414 & 59.3 \\
\hline Average level & 59 & 8.5 \\
\hline High Income level & 225 & 32.2 \\
\hline \multicolumn{3}{|l|}{ Educational Level } \\
\hline Low educational level & 665 & 95.3 \\
\hline Medium Educational level & 22 & 3.2 \\
\hline High educational level & 11 & 1.5 \\
\hline
\end{tabular}

Source: Field Survey, 2014 
The adoption level of the technique was determined by providing the processors with a number of techniques with yes or no option to indicate the technique presently in use for rice parboiling. Those that indicated yes for the technique in question (Tadco) were categorized as Adopters while others were referred to as Non-Adopters. As shown in Table 3; few of the respondents (1.7\%) adopted the technique while majority $(98.3 \%)$ can be referred to as non-adopter.

Table 3: Adoption of Tadco Technique among Respondents.

\begin{tabular}{llc}
\hline Adoption Category & Frequency & Percent \\
Adopters & 12 & 1.7 \\
Non Adopters & 686 & 98.3 \\
\hline
\end{tabular}

\section{Source: Field Survey 2014}

Table 4: Logit Model of Parboiler's Socio-economic Variables and Non Adoption of Improve Tadco Parboiling Technique.

\begin{tabular}{|c|c|c|c|}
\hline $\begin{array}{l}\text { Variables } \\
\text { Age }\left(x_{1}\right)\end{array}$ & coefficient (B) & $\operatorname{Exp}(B)$ & sig \\
\hline Less than or equals 40 & & & \\
\hline $\begin{array}{l}\text { Greater than 40yrs } \\
\text { Educational level }\left(x_{2}\right)\end{array}$ & -2.046 & 0.129 & $0.004^{*}$ \\
\hline $\begin{array}{l}\text { High educational level } \\
\text { Low educational level } \\
\text { Parboiling experience } \\
>6 \text { yrs }\end{array}$ & 2.560 & 12.936 & $0.007^{*}$ \\
\hline $\begin{array}{l}<6 y r s(r) \\
\text { Income }\left(x_{4}\right)\end{array}$ & 16.721 & 1.827 & 0.999 \\
\hline $\begin{array}{l}\text { High income } \\
\text { Low income }(r) \\
\text { Occupational members }\end{array}$ & 0.472 & 1.603 & 0.491 \\
\hline $\begin{array}{l}\text { Member } \\
\text { Non member }(r) \\
\text { Cooperative membersh } \\
\text { Member }\end{array}$ & 17.029 & 2.486 & 0.998 \\
\hline $\begin{array}{l}\text { Non member( } r) \\
\text { Exposure level to imprc } \\
\text { Expose }\end{array}$ & $\begin{array}{r}0.916 \\
\left.x_{7}\right)\end{array}$ & 2.500 & 0.434 \\
\hline $\begin{array}{l}\text { Not Expose }(r) \\
\text { Marital Status }\left(x_{8}\right) \\
\text { Married }\end{array}$ & 0.209 & 1.233 & 0.790 \\
\hline Not Married ( r) & -0.156 & 0.856 & 0.894 \\
\hline Constant & 1.424 & 4.153 & 0.146 \\
\hline -2loglikelihood & 105.339 & & 0.000 \\
\hline Model chi square & 15.973 & & 0.000 \\
\hline ox \&snell R square & 0.026 & & \\
\hline Nagelkerke R square & 0.162 & & \\
\hline Overall classification & 98.3 & & \\
\hline
\end{tabular}

$\mathrm{N}=698{ }^{*}$ Significant at .05 level, $\quad \mathrm{r}$-reference category, $\mathrm{df}=1$ (for each independent variable) 
The model chi square (Table 4) is significant at 0.05 level and can therefore be referred to as a good fit. It explains between $2.6 \%$ and $16.2 \%$ variation in non-adoption of Tadco technique. Since the 2loglikelihood $p$ value 0.000 is less than 0.05 , the null hypothesis is rejected and conclusion reached that a significant relationship exist between personal characteristics and non-adoption of innovation. Age and educational level of parboilers and adoption are found to be statistically significant. Educational level of parboilers is positively related to non-adoption of tadco technique while age is negatively related to the dependent variable. According to the odd ratio, an old category of female parboiler is almost $13 \%$ less likely than their younger counterpart to put on a negative adoption behaviour while those with a low level of education are 12 times more likely than their counterpart with high educational level to fall in non adopters' category of tadco parboiling technique. The equation can be deduced from table 4 and given as follows;

Logit $P=1.424-2.046 x_{1}+2.560 x_{2}+16.721 x_{3}+0.472 x_{4}+17.02 x_{x 5}+0.916 x_{6}+0.209 x_{7}-1.56 x_{8}$

The low level of education and exposure among the respondents must have been responsible for the enormous non adoption claimed by majority of the respondent. The number of respondents used in the study has confirmed the claims of researchers that Nigerian women produce between $60-80 \%$ of agricultural food in the country while rural women have been noted to account for seventy percent $(70 \%)$ of agricultural workers, eighty percent $(80 \%)$ of food producers and are engaged in the processing of basic foodstuffs (Mafimisebi, 2007; Mohammed and Adullahi, 2012). Almost all respondents are married $(96 \%)$ while most parboilers interviewed; $49.3 \%$ of the parboilers are between $31-35 \mathrm{yrs}$ of age. This implies that the processor are in their economically active and reproductive stage of child bearing. (Anyiro et. al., 2015)

The situation of female farmers as discovered in the study, reaffirms what was noted in the work of Ejembi et. al., (2006), who posited that most problems encountered by women in food chain activities were inadequate time for farming due to too much domestic activity, poor financial resources and poor storage facilities. Most rural women farmers are of low income and low level of education; this detached them from going into capital intensive farming such as poultry production and other relatively large scale rice processing. The low income status of women limits their opportunity for broader participation in society compounded by the trouble they experienced in child bearing and rearing.

The regression analysis shows that age, and educational level exhibits a dependent association with non adoption of tadco parboiling technique. Research has confirmed the above findings to be true as (Agbamu et. al., 1996; Ezebuiro 2008) posited that level of education among farmers yielded positive significant relationship to adoption of improved varieties and technologies and that the more the farmers advance in their level of education, the more they tend to understand the importance, intricacies and need for adopting new improved farm practices. It aids farmers and lead them to accept new farm technologies more readily to improve their income than those farmers without a formal education.

A negative relationship exists between age and adoption of innovation, the odd value revealed that the old category of parboiler, is almost 12 percent less likely than their younger counterpart in exhibiting a negative adoption behaviour. This is in contrast with the adoption theory which states that a young age is a good ground for the success of any extension campaigns and programs that aims at dissemination and adoption of any agricultural innovations, as young farmers have been found to be more innovative than their older counterparts (Rogers, 1993)

Reasons for the formed attitude towards the technique were unraveled during the Focus group discussion. Several parboilers among those who found the knowledge as not useful give reasons such as getting burnt easily while using the drum, rusting of drum and discoloring of rice as well as high 
consumption of firewood. Some of them said the drum is rather too high, thereby making it tedious to work with. The following comments were passed by the parboilers:

Using the drum is tedious and we get burnt easily. Even if we want to collect the rice from the drum, it is always very tedious because the drum is too tall for us. (female parboiler, Member of Tamborawa association) .......the drum consume a lot of firewood which is expensive to purchase (Female parboiler, member of Gidan Zago women parboiler, Kura.)

Majority of the group members, more than half said no contact exist between them and the trainers after the completion of the training. When they were asked for the reason preventing them from reaching out to the trainer, several group members claim the inability to locate the trainers since the training exercise.

The trainers are not aware of the shortcomings because we did not have any contact with them since the end of the training and we did not see them again (Female parboiler, Karfi Kofa Udu Gidan Alh Abdu Shinkafa Parboilers Ass)

Despite the above, majority of the parboilers claimed that the knowledge gained from the training is useful to them. They are now able to parboil more quantity of paddy after the training session as a result of gained skills and confidence in parboiling using the old technique.

As a result of the training, I am able to do more than I used to do before training" (Female parboiler, Member of Tamburawa parboilers Association)

The training was useful because we learnt the proper washing of rice before parboiling, how to do the parboiling very well, drying and general processing. (Female parboiler, Member of Tamburawa parboilers Association)

According to the respondents, more knowledge was gained on proper washing of rice, controlling of power source to have well parboiled rice as well as proper and hygienic drying. This experience has given them more confidence and has been inculcated into their parboiling process using their traditional method even when the drum was found to be unfavourable at the long run. Hence, the advantage has been seen by few of the parboilers in skills acquisition and gaining of confidence in their processing.

\section{CONCLUSION AND RECOMMENDATIONS}

The future of Nigerian rice sector as well as the improvement in women parboilers' income depend largely on the quality of rice produced within the country for both local consumption and exportation. Low quality of rice as a result of deficiency such as the presence of pebbles, chaffs and broken grains are attributable to the traditional processing technique largely used by the parboilers.

Sequel to the findings of this study, attention should be given to socio demographic variables such as level of exposure and educational status of the rural women populace. Education is a vital factor for innovativeness, as well as an influential variable in promoting social change in our rural areas and the society at large. Exposure of the female parboilers to improve parboiling technique will encourage them to team up and access various means such as cooperative society in access the favourable parboiling equipments as well as improve the procedure involved in order to avoid pebbles and other strange materials which might make the final product incomparable with the imported rice. Also an educated parboiler will keep records of their dealings with the trainers thereby making it easier to locate the trainers and lodge their complaints while an educated female rice parboiler will select a leader with the right attitude and capability when dealing with outsider such as the manufacturers of Tadco technique of rice parboiling. 
Creation and proper monitoring of diverse social networks among the female parboilers will also enhance their exposure level and leadership qualities. On the part of change agents, the felt need of their clients should be properly evaluated before the introduction of an innovation. Bridging the gender gap as regards model construction and maintenance should be a priority in constructing any agricultural technology due to the huge participation of Nigerian women in agriculture especially in food processing. This is not enough but the establishment of a viable means of communication should be made available in order to receive necessary feedback on the introduced technique, this becomes paramount as it was discovered that a large majority of the respondents in the study claimed their inability to make feedback on the shortcomings of the technique because they could not locate their trainers.

Finally, all necessary assistance either financial or technical assistance should be rendered to the female parboilers by stakeholders in the field of agriculture so as to ensure a good quality of parboiled rice which can compete with the imported rice. This can be achieved by empowering the rice parboilers through the provision of an effective and affordable technology which will meet the dire needs of the parboilers for qualitative food availability and sustainability in the country.

\section{References}

Adekunle .J. (2013). Nigerian spend N674Billion in Importation of Rice, Others. The Nations,Friday July 5,Lagos:11.

Agbamu J.U, Fujita .Y, Idowu I, and Lawal A. (1996). Effect of Socio-economic Factors on Adoption of New Varieties of Maize and Cassava. A Case study of Ogun State in Nigeria. Journal of Agricultural Development Studies Vol 6(2): 8-16.

Aminu A,A.M Hassan,A.Sulaiman and M.B Bello(2010). 'Technical Cooperation for Development Planning on the One Local Government One Product Programme for Revitalizing the Rural Economy in the Federal Republic of Nigeria, Kano State Report

Anyiro C.O (2015). 'The effect of Social Capital on access to micro credit among rural farming households in Abia State, Nigeria. Agrosearch Vol 15(1) 59-75.

Badayi M. S. and Said S. (2006). The Structure of Kano Economy. Kano State Website.

Daramola .B.(2005). Government Policies and Competitiveness of Nigerian Rice Economy. A Paper presented at the workshop on Rice Policy and Food Security in Sub-Saharan Africa, Organized by WARDA Cotonue, Republic of Benin, Nov 7-9.

Ejembi E.P, Ejembi S.A, Nabgulu (2006). Food Chain activities of women in an agrarian community in central Nigeria: Implication for rural development. Journal of Human Ecology.19 (1):63-67.

Ekong E.E (1998) An Introduction to Rural Sociology pp 323-342

Ezebuiro, N.C Ironkwe A.G Ugbaaya C.C. Chinak A. E.C and Chukwu G.O. (2008). Impact of adopting Improved Cassava varieties among farmers in the coastal plain soil of Umaahia Agricultural zone of Abia State. Proceedings of the seventeenth Annual Congress of Nigerian Rural Sociological Association.

Eziehe J.A.C., Agbugha I. K. and lornum W. (2014). Assessment of Rural Women Participation in Processing and Marketing of Soyabeans in Tarka Local Government Area of Benue State, Nigerian Current Agricultural Research Journal (2)1. pp 821

Fabiyi E. F. and B.M Hamidu (2011). Adoption of Improve Technology in Soaybeans processing and Utilization in Tafawa Balewa Local Government Area of Bauchi State, Nigerian African Journal of Food, Agriculture, Nutrition and Development. 11 (1): 4460-4475.

Federal Ministry of Agriculure and Rural Development (FMARD) (2012). Commercial Feasibility Study Report for the Establishment of Rice Processing Mills in Nigeria, Accenture, Nigeria pp 79. 
Jamsari, H., Jasmine, A. M., Norhamidah, J., Suwaiba, Z. \& Nordin, M. (2012). Factors Associated with the Continuality of Agricultural Innovation Adoption in Sabah, Malaysia Journal of Sustainable Development 5:1 www.ccsenet.org/jsd

Kano State Agricultural and Rural Development Authority, (2007). Rice upgrade and Production in Kano State.

Mafimisebi T.E (2007). A Comparative Economic Analysis of Two cassava based Business activities Exclusive to the Female gender in Oyo State of Nigeria. Journal of Agricultural Extension 10: 10.

Matanmi B.M, G.B Adesiji, E.M. Olasheinde and F.O Oladipo (2011). Assessment of Usage of Upgraded indigenous Shea butter Processingt technology by Women Processors in Kwara State, Nigeria. Agrosearch 2010\& 2011, 11(1\&2):19-30.

Muhammed B.T and A.F Abdullahi (2012). Comparative Analysis of gender involvement in Agricultural Producion in Nigeria. Journal of Development and Agricultural Economics.Volume 4(8):240-244 .

Ogunfiditimi.T.O (1981). Adoption of Improved Farm Practices: A Choice under Uncertainty".Indian Journal of Extension Education XVII:30-35

Okafor L.A (1986). "The Problems of rural Farmers in Nigeria Daily Times Publication, Lagos

Okoruwa V.O and Ogundele 0.0 (2006). Technical Efficiency Differentials in Rice Production Technologies in Nigeria. Agric Research Paper 134, African Economic Research Consortium, Nairobi.

Onwalu A.P (2012). Agricultural Sector and National Development:Focus on value Chain Approach, Paper presented at Sharon House,GRA Onitsha on 24th May 2012.

Okoruwa V.O and Ogundele 0.0 (2006). Technical Efficiency Differentials in Rice Production Technologies in Nigeria. Agric Research Paper 134, African Economic Research Consortium, Nairobi.

Osondu C.K (2014). Determinant of decision for Nonfarm Entrepreneurship by Women farmers in Ikwuano Local Government Area, Abia State. Agrosearch 14(2):30. www.ajol.info/index.php/agrosh.

PrOpCom (2007). Managing Demonstration of Improved Parboiling Equipment in Kura-Kano Rice Processing Cluster. Making Nigerian Agricultural Market Work for the Poor. Monograph Series \# 24.

PrOpCom newsreel (2007). Parboiling of Paddy Rice Making Nigerian Agricultural Market Work for the Poor. Volume 1, No 3

Rogers, Everett M. (1995) Diffusion of Innovations. $4^{\text {th }}$ ed. New York: Free Press.

Sarr,F (1999) "The promotion of Income Generating Activities" A Paper Presented at the co seminar on The Economic role of Women in Rural and Agricultural Development Anthens, Greece 1822 October.

USAID MARKETS (2010). Improved Packaging of Practices for Rice Production: A production Manual for Agricultural Workers in Nigeria.

National Bureau of Statistics (2007) Agricultural Survey Report 1994-2006 